\title{
GOVERNMENT'S EFFORTS TO PREVENT POTENTIAL VIOLENCE AGAINST WOMEN DURING THE COVID-19 PANDEMIC IN INDONESIA
}

\author{
Devid Frastiawan Amir Sup \\ Fakultas Syariah Universitas Darussalam Gontor \\ devidfrastiawan@unida.gontor.ac.id
}

\begin{abstract}
Abstrak: Implementasi Pembatasan Sosial Berskala Besar (PSBB) di Indonesia untuk mencegah penyebaran yang lebih luas dari pandemi Covid-19, dalam perjalanannya ternyata membawa dampak sosial-ekonomi, yang dalam skala rumah tangga dapat berpotensi menimbulkan tindak kekerasan di dalam rumah tangga. Wanita, khususnya, adalah mereka yang berpotensi menjadi korban tindak kekerasan tersebut, terlebih pada masa pandemi ini. Penelitian ini bertujuan untuk mendeskripsikan upaya-upaya yang diambil oleh pemerintah Indonesia dalam mencegah potensi tindak kekerasan terhadap wanita selama masa pandemi Covid-19. Penelitian ini menggunakan metodologi kualitatif-deskriptif-kepustakaan. Hasil yang didapat yaitu untuk mengatasi beberapa dampak sosial-ekonomi yang muncul, pemerintah mengambil upaya melalui program-program jaring pengaman sosial. Selanjutnya, untuk mencegah potensi tindak kekerasan terhadap wanita selama masa pandemi ini, pemerintah mengambil upaya melalui penerapan Protokol Penanganan Kasus Kekerasan terhadap Perempuan di Masa Pandemi Covid-19. Tujuan dari penelitian ini adalah menjelaskan bahwa sebenarnya pemerintah memiliki perhatian khusus untuk menjamin tersedianya instrumen hukum dalam pencegahan dan perlindungan bagi korban tindak kekerasan terhadap perempuan selama masa pandemi ini. Kemudian, melalui penelitian ini, peneliti mengajak untuk dapat bersama-sama mendukung upaya-upaya yang telah diambil oleh pemerintah dalam meminimalisir dampak sosial-ekonomi pandemi Covid-19, sehingga harapannya dampak tersebut agar dapat segera terselesaikan dengan baik.
\end{abstract}

Kata Kunci: Pembatasan Sosial Berskala Besar; Dampak Sosial-Ekonomi; ProgramProgram Jaring Pengaman Sosial, Protokol

Abstract: The implementation of Large-Scale Social Restrictions (Known as PSBB) in Indonesia for preventing the wider spread of the Covid-19 pandemic, ultimately had socio-economic impacts, which then for households it had the potential to cause domestic violence. Women were vulnerable to become victims of violence, especially during this pandemic. This research describes the efforts taken by the government in Indonesia in preventing potential violence against women during the Covid-19 pandemic. This research uses qualitative-descriptive-textual methods. The results of this research are, to overcome these socio-economic impacts, the government had taken efforts through social safety net programs. Furthermore, to prevent the 
potential for violence against women during this pandemic, the government took the effort by implementing the Protocol on the Handling of Cases of Violence Against Women in the Covid-19 Pandemic Period. The purpose of this research is to explain that the government had special attention to ensure the availability of protection for victims of violence against women during this pandemic. Furthermore, through this research, the researcher encourages to support the efforts taken by the government to minimize the socio-economic impact of the Covid-19 pandemic, so that it can be resolved immediately.

Keywords: Large-scale social restrictions; Socio-economic impacts; Safety net programs; Protocol.

\section{INTRODUCTION}

Since the first case of Covid-19 in Indonesia, the government had begun to make various efforts in preventing and managing it. Slowly, this pandemic began to have an impact, especially in the socioeconomic field. The space for human life was started to be limited, income had been declined, and many people lost their jobs. They were increasing conditions that had put psychological pressure on some people. To this day, the number of positive cases of Covid-19 continued to increase, and it could not be predicted how long the pandemic will end. With this condition, with the psychological condition of people who were depressed, women were very vulnerable to becoming victims of violence during this pandemic.
The findings of the Women's National Commission showed that the pandemic greatly impacts the lives of women. There had been an increase in the workload of women at home due to the work being directed at women resulting in increased violence. ${ }^{1}$ This research aims to describe the efforts taken by the government in Indonesia in preventing potential violence against women during the Covid-19 pandemic. Efforts described are in the form of policies issued by the government to protect women from domestic violence that might occur during this pandemic.

From the problems that have been described previously, it is important to search from the results of other researches. The aim is to give clarity to the issues discussed in this research. First,

\footnotetext{
1 Komisi Nasional Perempuan Republik Indonesia, "Angket Survey: Pemetaan Kondisi Layanan Pendampingan Perempuan Korban Kekerasan dan Kondisi Perempuan Pembela HAM di Masa Covid-19,"

news-angket-survey-pemetaan-kondisi-layananpendampingan-perempuan-korban-kekerasandan-kondisi-perempuan-pembela-ham-di-masacovid-19, 08 May 2020, visited on 26 November 2020.
} https://www.komnasperempuan.go.id/read- 
research from Silpa Hanoatubun, the impact of the Covid-19 pandemic on the Indonesian economy caused severe pressure on all sectors of the economy. ${ }^{2}$ Second, research from Rahma Ainul Mardiyah and R. Nunung Nurwati, there were over 2 million workers affected by the Covid-19 pandemic. This pandemic also had an impact on increasing the number of unemployed people in Indonesia. ${ }^{3}$ Third, research from Wibowo Hadiwardoyo, individual losses due to the Covid-19 pandemic were income reductions, fines/interest payment due too late/non-payment of obligations, extra expenses during the pandemic, new debt interest, and job losses. ${ }^{4}$ Fourth, research from Engkus, and et. al., Indonesian government policy did not be a serious focus in handling the Covid-19 pandemic. Consequently, it was difficult to minimize the deeper and more serious socio-economic impacts. ${ }^{5}$ Fifth, research from Putu Agung Nara Indra Prima Satya, Covid-19 pandemic triggered social conflicts in the society, which occurred

2 Silpa Hanoatubun, "Dampak Covid-19 Terhadap Perekonomian Indonesia," EduPsyCouns: Journal of Education, Psychology and Counseling 2, No. 1 (2020): 146.

3 Rahmah Ainul Mardiyah, and R. Nunung Nurwati, "Dampak Pandemi Covid-19 Terhadap Peningkatan Angka Pengangguran di Indonesia," https://www.academia.edu/download/63135109 /Artikel_Studi_Kependudukan_Rahma_Ainul_M ardiyah_17031018007620200429-10214810xmp8n.pdf, visited on 26 November 2020. horizontally (among peers) and vertically (between government and society). ${ }^{6}$

From all research, no research found other socio-economic impacts of the Covid-19 pandemic in Indonesia, especially in the efforts of the Indonesian government to prevent potential violence against women during this pandemic. This is considered very important for discussion, because women are very vulnerable to becoming victims of violence, especially during the Covid-19 pandemic.

\section{METHOD}

This research uses qualitativedescriptive-textual methods. This research is limited to the use of textual data. Data from this research include data on Covid-19 in Indonesia, these impacts, and policies taken by the government; data on violence against women in Indonesia; as well as, data on policies issued by the government which aims to protect women against potential violence that might occur during the Covid-19 pandemic in Indonesia. The data

4 Wibowo Hadiwardoyo, "Kerugian Ekonomi Nasional Akibat Pandemi Covid-19," Baskara 2, No. 2 (2020): 88.

5 Engkus, and et. al., "Covid-19: Kebijakan Mitigasi Penyebaran dan Dampak Sosial Ekonomi di Indonesia," http://digilib.uinsgd.ac.id/30820, 05 May 2020, visited on 26 November 2020.

6 Putu Agung Nara Indra Prima Satya, "Covid-19 dan Potensi Konflik Sosial," JIII: Jurnal Ilmiah Hubungan Internasional, Special Edition (2020): 39-45. 
collection is sorted according to the needs of the research purpose. The analysis process is from the beginning to the end during the writing process. The analysis process is carried out by interpreting data, translating languages, editing words, and then arranging through a logical systematic, so that the description to be built can be conveyed properly.

\section{RESULTS AND DISCUSSION}

1. The Social-Economic Impacts of the Covid-19 Pandemic in Indonesia

Covid-19 is the infectious disease caused by the most recently discovered coronavirus. This new virus and disease were unknown before the outbreak began in Wuhan, China, in December 2019. Covid-19 is now a pandemic affecting many countries globally. ${ }^{7}$ People can catch Covid-19 from others who have the virus. The disease spreads primarily from person to person through small droplets from the nose or mouth, which are expelled when a person with Covid-19 coughs, sneezes or speaks. People can catch Covid-19 if they breathe in these droplets from a person infected with the virus. This is why it is important to stay at least 1 meter away from others. ${ }^{8}$ Globally, until November 25, 2020, there have been 59.481.313 confirmed cases of Covid-19, including 1.404.542 deaths. ${ }^{9}$

The first positive Covid-19 case in Indonesia was announced by the government on March $2^{\text {nd }}, 2020$, who were 2 Depok residents, West Java, who were infected with the coronavirus due to contact with Japanese citizens who came to Indonesia. ${ }^{10}$ Globally in Indonesia, until November 25, 2020, there had been 511.836 confirmed cases of Covid-19, including 65.804 active cases, 429.807 recovered, and 16.225 deaths. ${ }^{11}$

Since Indonesia has become one of the countries affected by Covid-19, several regulations have been issued by the government. To prevent the spread

\footnotetext{
${ }^{7}$ World Health Organization (WHO), "Q\&A on Coronaviruses (Covid-19): What is a Covid19 ?"

https://www.who.int/emergencies/diseases/nov el-coronavirus-2019/question-and-answershub/q-a-detail/q-a-coronaviruses, 12 October 2020, visited on 26 November 2020.

8 World Health Organization (WHO), "Q\&A on Coronaviruses (Covid-19): How does Covid-19 Spread?"

https://www.who.int/emergencies/diseases/nov el-coronavirus-2019/question-and-answershub/q-a-detail/q-a-coronaviruses, 12 October 2020, visited on 26 November 2020.

9 World Health Organization (WHO), "Globally Confirmed Cases of Covid-19,"
}

https:// covid19.who.int/ ?gclid=CjwKCAjw_LL2 BRAkEiwAv2Y3SbX6-

E_05NX0PIVKP26v7Y5kQLJ9PSBZmSbcin880 nW1zHcL6VWy7xoCz3MQAvD_BwE, 26 November 2020, visited on 26 November 2020.

${ }^{10}$ Kompas, "Fakta Lengkap Kasus Pertama Virus Corona di Indonesia," https://nasional.kompas.com/read/2020/03/03 /06314981/fakta-lengkap-kasus-pertama-viruscorona-di-indonesia, 03 March 2020, visited on 26 November 2020.

11 Satuan Tugas Penanganan Covid-19 Republik Indonesia, "Peta Sebaran," https://covid19.go.id/peta-sebaran, 26 November 2020, visited on 26 November 2020. 
107 | Devid Frastiawan Amir Sup, Government Efforts to..., pp. 103 - 124

of this pandemic, the government implemented large-scale social restrictions through Government Regulation on Large-Scale Social Restrictions in the Context of Accelerating the Handling of Coronavirus Disease 2019 (Covid-19) $^{12}$ and Minister of Health Regulation Regarding Guidelines for Large-Scale Social Restrictions in the Context of Accelerating the Handling of Coronavirus Disease 2019 (Covid-19). ${ }^{13}$ Large-scale social restrictions are restrictions on certain activities of residents in an area suspected of being infected with Coronavirus Disease 2019 (Covid-19), including restrictions on the movement of people and goods for a province or district/city region, to prevent the possible spread of Covid-19. To be able to set large-scale social restrictions, a province/district/city region must meet the following criteria: The number of cases and/or the number of deaths due to disease had increased and spread significantly and rapidly to several regions; and, there was an epidemiological connection with similar

12 Sekretariat Kabinet Republik Indonesia, "Peraturan Pemerintah No. 21 Tahun 2020," https://jdih.setkab.go.id/PUUdoc/176085/PP_ Nomor_21_Tahun_2020.pdf, 03 March 2020, visited on 26 November 2020.

13 Kementerian Kesehatan Republik Indonesia, "Peraturan Menteri Kesehatan No. 9 Tahun 2020," http://hukor.kemkes.go.id/uploads/produk_huk incidents in other regions or countries. Large-scale social restrictions included: Freeing schools and workplaces; Restrictions on religious activities; Restrictions of activities in public places or facilities; Restrictions of social and cultural activities; Restrictions of transportation modes; and, Restriction on other activities, specifically related to defense and security aspects.

The implementation of large-scale social restrictions caused economic impacts during the Covid-19 pandemic in Indonesia. These impacts also raised several social problems such as unemployment and violence. As of April $20^{\text {th }}, 2020$, the number of workers affected by Covid-19 was 2.084.593 workers from the formal and informal sectors from 116.370 companies. The number of companies and returning formal workers was 1.304.777 from 43.690 companies. While formal workers laid off were 241.431 workers from 41.236 companies. The informal sector lost 538.385 workers affected from 31.444 companies or UMKM (micro and small businesses). ${ }^{14}$

um/PMK_No_9_Th_2020_ttg_Pedoman_Pemb atasan_Sosial_Berskala_Besar_Dalam_Penangana n_COVID-19.pdf, 03 April 2020, visited on 26 November 2020.

14 Kementerian Ketenagakerjaan Republik Indonesia, "Menaker: Badai Pasti Berlalu, Panggil Kembali Pekerja yang ter-PHK Nanti," https://www.kemnaker.go.id/news/detail/mena ker-badai-pasti-berlalu-panggil-kembali-pekerja- 
Then, until May $28^{\text {th }}, 2020$, the number of victims of violence against women throughout 2020 in Indonesia was 3477 people. Of most female victims, $32.1 \%$ were $25-44$ years old, and $30.3 \%$ were $13-18$ years old. According to their work, the most female victims, $33.3 \%$ were students, and $22.3 \%$ were housewives. Whereas according to the location of the incident, at most, $62.0 \%$ were at home. ${ }^{15}$

\section{Government's Efforts to Prevent} Potential Violence Against Women During the Covid-19 Pandemic in Indonesia

The Covid-19 pandemic caused the world economy to experience severe pressure. ${ }^{16}$ This pandemic had the potential to ignite the economic crisis. ${ }^{17}$ It was marked by stalled production activities in many countries, falling levels of public consumption, decreasing

yang-ter-phk-nanti, 22 April 2020, visited on 26 November 2020.

15 Kementerian Permberdayaan Perempuan dan Perlindungan Anak Republik Indonesia, "SIMFONI PPA (Sistem Informasi Online Perlindungan Perempuan dan Anak)," https://kekerasan.kemenpppa.go.id/ringkasan, 28 May 2020, visited on 28 May 2020.

16 Chairul Ihsan Burhanuddin, and Muhammad Nur Abdi, "Krisis Ekonomi Global dari Dampak Penyebaran Virus Corona (Covid19)," AkMen 17, No. 1 (2020): 90.

17 Asri Kusuma Dewanti, "Darurat PHK di Tengah Corona," https://www.harianbhirawa.co.id/darurat-phk-ditengah-corona/, 07 April 2020, visited on 26 November 2020.

18 Aknolt Kristian Pakpahan, "Covid-19 dan Implikasi bagi Usaha Mikro, Kecil, dan consumer confidence, the collapse of the stock market which ultimately leads to uncertainty. ${ }^{18}$ The impact of the Covid19 pandemic ultimately led to the economic downturn of society and the country, which then led to various social problems. ${ }^{19}$

At the end of March 2020, the Indonesian President finally decided to implement the large-scale social restriction in some cities and provinces, instead of regional quarantine. The government also emphasized the need to stay at home for all Indonesian citizens. ${ }^{20}$ This policy had a positive goal to avoid the more fatal consequences of the widespread pandemic Covid-19. ${ }^{21}$ However, this policy also affected many companies that had to be closed down, employees were laid off, and some even had to lose their jobs. ${ }^{22}$ The unemployment rate had also increased. This problem made it possible to bring

Menengah," JIII: Jurnal Ilmiah Hubungan Internasional, Special Edition (2020): 59-64.

19 Syafrida, and Ralang Hartati, "Bersama Melawan Virus Covid-19 di Indonesia," Salam 7, No. 6 (2020): 495-508.

20 Siti Setiati, and Muhammad Khifzhon Azwar, "Covid-19 and Indonesia," Acta Medica Indonesiana 52, No. 1 (2020): 85.

21 Deni Kamaludin Yusup, and et. al., "Pengaruh Bencana Covid-19, Pembatasan Sosial, dan Sistem Pemasaran Online Terhadap Perubahan Perilaku Konsumen dalam Membeli Produk Retail," http://digilib.uinsgd.ac.id/30872, 04 July 2020, visited on 26 November 2020.

22 Indra Rahmatullah, "Jaminan Hak Kesehatan Pekerja Work From Office Selama Masa PSBB Covid-19," 'Adalah 4, No. 1 (2020): 58. 
up various kinds of crimes or violence. ${ }^{23}$ Large-scale social restrictions also had the potential to create social conflicts. ${ }^{24}$ It caused the increasing social anxiety for various reasons: First, the anxiety of uncertainty about the time when the spread of the coronavirus could be resolved; Second, anxiety about the future of life due to income reduction or loss of work; Third, anxiety of staying too long at home without any activity and work. Then, the anxiety caused various psychological pressures that negatively impact on family, household, and society. ${ }^{25}$

In the current situation and conditions, government policy is very important to save Indonesian citizens in the future. ${ }^{26}$ Before the outbreak of the Covid-19 pandemic, the government had implemented several social protection programs, which were manifested in social assistance and non-contribution, as

23 Siti Ngainnur Rohmah, "Adakah Peluang Bisnis di Tengah Kelesuan Perekonomian Akibat Pandemi Corona?' 'Adalah 4, No. 1 (2020): 67-68.

24 Anisa Mufida, "Polemik Pemberian Bantuan Sosial di Tengah Pandemic Covid-19," 'Adalah 4, No. 1 (2020): 162.

25 Moch. Fakhruroji, and et. al., "Strategi Komunikasi Publik Penanganan Covid-19 di Indonesia: Perspektif Sosiologi, Komunikasi Massa, dan Agama," http://digilib.uinsgd.ac.id/30753/1/Strategi\%20 Komunikasi\%20Publik\%20Penanganan \%20Covi d_KTI.pdf, visited on 26 November 2020.

26 Yoshua Consuello, "Analisis Efektivitas Kartu Pra-Kerja di Tengah Pandemi Covid-19," 'Adalah 4, No. 1 (2020): 94.

27 Ah Maftuchan, "Program Tunai di Era Covid-19: Bantuan Tunai Korona atau Jaminan Penghasilan Semesta," well as social security and contributions. ${ }^{27}$ To prevent the spread and socioeconomic impact of this pandemic, the government then took several policies. ${ }^{28}$ These policies were the development of social protection programs that had been carried out previously by the government with various adjustments, which were then called social safety net programs.

Social safety nets were economic stimulus packages provided by the government directly or indirectly, to help the economy of the people affected by the steps taken by the government in deciding the spread of the Covid-19 pandemic. $^{29}$ The government had prepared funds of around IDR 110 trillion allocated for social safety nets, for the lower classes to remain able to meet basic needs and maintain purchasing power. First, the expansion of the number of beneficiary families from PKH (Program Keluarga Harapan), which

https:/ / repository.theprakarsa.org/media/30109 4-policy-brief-21-program-tunai-di-era-cov-

400baa3c.pdf, April 2020, visited on 26 November 2020.

28 M. S. Wahyudi, "Opini Malang Post: Gerakan Sosial Atasi Dampak Ekonomi Covid$19, "$ report.umm.ac.id/index.php/APIBAA/article/download/3558/3478, 16 April 2020, visited on 26 November 2020.

29 Badan Nasional Penanggulangan Bencana (BNPB) Republik Indonesia, "Jaring Pengaman Sosial Kurangi Dampak Ekonomi Masyarakat di Tengah Pandemi Covid-19," https://bnpb.go.id/berita/jaring-pengamansosial-kurangi-dampak-ekonomi-masyarakat-ditengah-pandemi-covid19, 16 April 2020, visited on 26 November 2020. 
originally amounted to 9.2 million recipients to 10 million, with an increase of benefits by $25 \%$, and distribution was accelerated from 3 months to once a month. Second, the recipients of the nine basic food cards (Kartu Sembako) were raised from 15.2 million to 20 million beneficiaries, with an increase of $30 \%$, from IDR 150.000 to IDR 200.000, and given for 9 months. Third, Jabodetabek (Jakarta, Bogor, Depok, Tangerang, Bekasi) prepared a special social assistance program for 3.7 million familybased for 2 months (the emergency response period established by the Covid-19 Task Force), and 200.000 food packages were distributed. Fourth, the pre-employment card (Kartu Prakerja) began on April $9^{\text {th }}$. The budget was raised from IDR 10 trillion to IDR 20 trillion, and beneficiaries were 5.6 million people, especially for those affected by layoffs, informal workers, micro and small businesses affected by Covid-19. Fifth, electricity tariffs for 24 million 450VA customers were being freed, and 7 million 900VA customers were discounted to $50 \%$ during April, May, and June. Because the program was important for citizens, the Indonesian President emphasized several things: The implementation must be truly on target, which data from beneficiary groups were precise and accurate, involving RT/RW, village government, and local government; Distribution was immediate, appropriate, and fast; Distribution mechanism was made as efficient as possible, using practical methods, not convoluted, and did not complicate the society; and, The mechanism involved the micro and small business sector, food staple vendors in the market, and taxi bikers. ${ }^{30}$

Furthermore, in the current Covid-19 pandemic, the socio-economic impacts also posed potential new problems, such as violence, those who were vulnerable to violence were women. The vulnerable violence for women during the current covid-19 pandemic was domestic violence or other gender-based violence.

Gender-based violence is often used together with the term violence against women because gender-based violence highlights the gender dimension in these forms of action. After all, gender construction has placed women's status as second class in society. And because of these unequal power relations, women are very vulnerable to violence. Forms of violence that may be experienced by
30 Sekretariat Kabinet Republik Indonesia, "Program Jaring Pengaman Sosial," https://setkab.go.id/gallery/program-jaring- pengaman-sosial, 08 April 2020, visited on 26 November 2020. 
111 | Devid Frastiawan Amir Sup, Government Efforts to..., pp. 103 - 124

women in this pandemic situation are physical, psychological, sexual violence, or neglect.

To ensure the availability of protection services for victims of gender-based violence, the government, through the Ministry of Women's Empowerment and Child Protection, in this case, the Deputy for the Protection of Women's Rights (Kemenpppa) in collaboration with the United Nations Population Fund (UNFPA), compiled Protocol on the Handling of Cases of Violence Against Women in the Covid-19 Pandemic Period. These Available protocols include in the following explanations: ${ }^{31}$

\section{Complaints Protocol for Cases of Violence Against Women During the Covid-19 Pandemic}

For Online Media Services, each service institution made publications or KIE (communications, information, and education) related to services that could be accessed by reporters during the Covid-19 period. There were many roles of those Online Media Services including: (1) Each service institution ensures that in the Covid-19 pandemic period every complaint and consultation should use online media (telephone, whatsapp, email), or written media (letter); (2) Reports on complaints and consultation can contact each of the telephone numbers, whatsapp, and emails listed on KIE or publication media that have been made at each service institution; (3) The PP (recipient of the complaint) officer follows up on the report by contacting the reporter, if the reporter can be connected it will proceed with an initial assessment; (4) The complaints coordinator places a psychology and service officer to follow up on the case report as well as carry out routine checks on the stages of each service provided to each client while coordinating with the authorized officer; (5) PP officers and complaints coordinator record the performance/work records of each complaint on the hotline report sheet and/or available database.

Face-to-Face Services were provided by service institutions for cases that required immediate service due to legal status, psychological conditions, or risk of exposure. During the Covid-19 emergency response period, service institutions prioritized non-face-to-face services to minimize the spread of the

$\mathrm{kol} / 2020 \% 20-\% 200205-$

\%20PROTOKOL\%20LAYANAN\%20PEREM PUAN\%20DI\%20PANDEMI\%20COVID \%20\%208\%20PROTOKOL-1.pdf, 07 Mei 2020, visited on 26 November 2020. dan Perlindungan Anak Republik Indonesia "Protokol Penanganan Kasus Kekerasan Terhadap Perempuan di Masa Pandemi Covid19,"

https:// covid19.go.id/storage/app/media/Proto . 
virus. However, the urgency to handle violent cases could be the exception to non-face-to-face services The client indicators were taken into consideration for providing face-to-face services. The indicators related to the client's legal status were such as: (1) The verification process must be carried out immediately; (2) The suspect has been detained and/or is a child's age; (3) Process police reports and BAP (minutes of examination); (4) The trial process. Psychological conditions of the client: (1) The client shows intense psychological impact; (2) The results of the online assessment show that the impact is moderate to severe. The need for referrals to safe homes or medical services for treatment and medicolegal.

\section{Protocol for Providing Assistance Services for Victims of Violence Against Women During the Covid-19 Pandemic}

Outreach to be paid attention included: (1) Outreach to clients will use Molin (car protection)/other cars intended for client outreach; (2) Ensuring that before the client rides Molin/other cars, the officer checks the client's body temperature using a firing thermometer. If the client's health condition is in a bad situation, outreach can be canceled and the client referred to the health service; (3) The capacity of Molin/other cars must pay attention to large scale social restrictions (PSBB) or a maximum of 4 people; (4) Outreach officers ensure Molin/other cars have been disinfected before being used to deliver clients. Spray the seat, front seatback, pedestal, outside door handle, inside door area, top handle; (5) Ensuring the completeness of health support devices (masks, hand sanitizers, plastic, and backup folders) and supporting work required (2 pens, ID cards, assignments, or service forms) adjusted to the availability of service institutions; (6) During outreach, explain the Covid-19 procedure, conveying that this procedure must be followed for the safety and health of the client; (7) Before using Molin/other cars, make sure the officers clean their hands with a hand sanitizer and put the client documents in the plastic box that has been provided; (8) After returning from outreach, Molin/other cars are cleaned using a disinfectant; (9) Save the client file in a separate place.

Pickup or delivery of the client to be paid attention included: (1) The pickup and delivery officer ensures that Molin/other cars have been disinfected before being used to pick up clients. Spray the seat, front seatback, pedestal, outside door handle, inside door area, top handle; (2) Ensuring that before the client rides Molin/other cars, the officer checks the 
client's body temperature using a firing thermometer. If the client's health condition is in a bad situation, pickup/delivery can be canceled and the client referred to the health service; (3) Pickup and delivery officer ensures the completeness of health support devices (masks, hand sanitizers) and required work support (ID card, assignment letter, or service form) available; (4) The pickup and delivery officer ensures that the number of clients picked up is not more than 4 (including the delivery person); (5) The pickup and delivery officer makes sure to use a mask when doing his job; (6) When picking up, explain the Covid-19 procedure, convey that this procedure must be followed for the safety and health of the client; (7) Ask the client to use a hand sanitizer, see the basic protocol before entering Molin/other cars; (8) The pickup and delivery officer will open and close the door for the client, as well as adjust the sitting position so that the distance between passengers is at least 2 meters; (9) If the client shows a sick body condition, give a disposable mask to the client. When it comes down, ask the client to clean his hands again using a hand sanitizer; (10) Pick up and delivery officer cleans hands with hand sanitizer then clean Molin/other cars with disinfectant.

Case assistance to be paid attention included: (1) Case assistance for the client will use Molin (protection car) or other cars intended for client outreach; (2) Ensuring that before the client rides Molin/other cars, the officer checks the client's body temperature using a firing thermometer. If the client's health condition is in a bad situation, assistance can be canceled and the client referred to the health service; (3) Ensuring that Molin/other cars have been disinfected before being used to pick up clients. Spray the seat, front seatback, pedestal, outside door handle, inside door area, top handle; (4) Ensuring the completeness of health support devices (masks, hand sanitizers, plastics, and backup folders) and supporting work required (2 pens, ID card, assignment letter, or service form) available; (5) When the assistant explains the Covid-19 procedure, convey that this procedure must be followed for the safety and health of the client; (6) The officer will take notes using a different pen; (7) Before using Molin/other cars, make sure the officers clean their hand with a hand sanitizer and put the client's documents in the plastic box provided; (8) After returning from case assistance, Molin/other cars are cleaned using disinfectant; (9) Save the client file in a separate place.

Referral Protocol to Health Services for Victims of Violence Against 


\section{Women During the Covid-19 Pandemic}

Each institution prioritized online services to minimize the spread of the Covid-19 virus. However, for clients who needed medical services for treatment and medicolegal, face-to-face services could be provided based on the standard operational procedures of face-to-face services set by each institution.

These were some guidelines for making client referrals for health service: (1) The complaints officer will conduct a rapid assessment of the following health rehabilitation needs, for non critical services, for semi critical services, for critical services, for medicolegal services; (2) The case manager's complaint coordinator coordinates with the on call risk analysis team to carry out risk analysis procedures and client needs; (3) If the client requires to pick up, perform the client pick up procedure in a Covid-19 pandemic situation; (4) Based on the results of the risk analysis, the case coordinator will coordinate with health workers to refer clients to the health service (Puskesmas/RSUD/RS) appointed by the government or to the police for medical services; (5) For assistance to the police, refer to the security assistance protocol to the police; (6) The case coordinator coordinates with the health service (Puskesmas/RSUD/RS) staff appointed by the government in relation to the Covid-19 transmission prevention protocol at the Puskesmas or hospital; (7) The officer asks the client to fill out a willingness form to be referred to the Puskesmas or hospital; (8) The officer explains to the client about the procedures ata the health service (Puskesmas/RSUD/RS) appointed by the government, as well as the prevention procedure for Covid-19 transmission, information filling in the sceening form related to prevention of Covid-19 transmission, including if the client needs to handle Covid-19 isolation; (9) The officer discusses preparations if the client is tested positive Covid-19 while in isolation services, including if there are family dependents such as children, the elderly, family members with disabilities. Refer to shelter/safe house guidelines for families during the isolation period so that the families left are not with the perpetrators; (10) The officer (victim's assistant) will prepare a referral letter and initial chronological report to the health service; (11) Health workers from health service (Puskesmas/RSUD/RS) appointed by the government will pick up or service agency staff will deliver to health services following Covid-19 security provisions; (12) Officers record performance on service work forms and or intervention sheets; (13) Officers coordinate 
monitoring and receive reports from health workers.

\section{Referral Protocol to Safe Houses or Shelters for Victims of Violence Against Women During the Covid-19 Pandemic}

Service institutions could collaborate with safe houses/shelters to make referrals of clients with high emergency status, pay attention to the procedures and operational standards for safe houses/shelters and protocols during the Covid-19 pandemic including (1) The officer conducts a rapid assessment of the need for temporary shelter with one of the following indicators, the client is not willing to live in a family home and or does not have a near family, or the client feels threatened; (2) Client placement is based on the results of a risk analysis. Clients are referred to shelters with a low or moderate emergency level. Clients are referred to safe houses when emergencies are high; (3) The safe house coordinator or case coordinator coordinates with safe house officers/shelters regarding the Covid-19 transmission prevention protocol; (4) The officer asks the client to fill out a willingness form and screening form to be placed in a safe house/shelter; (5) The officer explains to the client about the shelter or safe house procedure and Covid-19 transmission prevention procedures. Includes information that clients need to be isolated independently for 14 days before moving with beneficiaries in a safe home. Clients can stay in a safe house according to operational standards procedures and extended if the client's conditions are not yet possible to be returned; (6) The officer (client's assistant) will prepare a referral letter and initial chronological report to the shelter/safe house; (7) Service personnel from shelter/safe houses will pick up; (8) The officer makes work records to be reported; (9) Officers coordinate for monitoring and receive periodic reports from safe house providers related to the development of clients in safe houses.

\section{Early Psychosocial Service Protocols Victims of Violence Against Women During the Covid-19 Pandemic}

Each service institution should conduct psychosocial services through online services either by telephone, video conferencing, or other online media agreed by the client. However, the urgency to handle violent cases could be the exception to non-face-to-face services.

The Online Psychosocial Services Preparation included: (1) Before conducting an online consultation, the counselor has obtained a list of clients who will be contacted from each complaint coordinator either through the 
whatsapp group or the email containing, initial assessment results, client contact numbers that can be contacted, scheduling time according to the consultation schedule in each institution; (2) The results of the initial assessment are a reference for discussion with the complaints coordinator before contacting the client; (3) The counselor will contact the client in the time preference for the consultation, and if 3 times the client does not respond, the counselor will mark the client and provide a list of clients who did not respond to the complaint officer to provide information to the client; (4) The counselor who contacts the client from the beginning to the end of the consultation should be the same counselor to maintain trust and at the same time avoid the risk of someone who exploits the client's situation.

Face-to-Face Psychosocial Consultation was carried out when the client was in an emergency condition such as suicidal ideation, anxiety, and feeling very scared, self-injury, and other emergency conditions. The preparations for this involved: (1) Make sure the room is sterilized. Spray the chairs, and the whole room; (2) Ensuring the completeness of health support devices (masks, hand sanitizers, plastics, and backup folders) and supporting work required (2 pens, ID card, assignment letter, or service form) available; (3) During the consultation explain the Covid-19 procedure, convey that this procedure must be followed for the safety and health of the client; (4) If the client requests pick up it will use the client pickup and delivery protocol.

The implementation for this protocol included: (1) Introduction by saying hello (salam), and then the consultation is focused on the psychological impact, efforts that have been made and provide psychoeducation information that can help clients to minimize the impact; (2) Identifying client needs for other services not previously mentioned in the initial assessment; (3) Asking the client's need for further consultation and the schedule has been agreed between the client and counselor; (4) Before the consultation closes, providing information if the client needs other services, the institution will call back from the same contact number to avoid the person acting on behalf of the institution and ask for the cost of the services provided are free; (5) The consultation concluded by conveying the conclusion of the conversation and saying thank you for your trust in the institution; (6) All results of the consultation will be recorded as well as reported in a worksheet; (7) All results of the consultation will be reported to the 
handling coordinator to be followed up for further assistance.

\section{Legal Consultation Service Protocol for Victims of Violence Against Women During the Covid-19 Pandemic}

Each service institution should conduct legal consulting services through online services either by telephone, video conferencing, or other online media agreed by the client. However, the urgency to handle violent cases could be the exception to non-face-to-face services.

The preparations for Online Legal Services included: (1) Before conducting an online consultation, TLH (legal service personnel) has obtained a list of clients who will be contacted from each complaint coordinator either through the whatsapp group or the email containing, initial assessment results, client contact numbers that can be contacted, scheduling time according to the consultation schedule in each institution; (2) The results of the initial assessment are a reference for discussion with the complaints coordinator before contacting the client; (3) TLH (legal service personnel) will contact the client in the time preference for the consultation, and if 3 times the client does not respond, TLH (legal service personnel) will mark the client and provide a list of clients who did not respond to the complaint officer to provide information to the client; (4) TLH (legal service personnel) who contacts the client from the beginning to the end of the consultation should be the same TLH (legal service personnel) to maintain trust and at the same time avoid the risk of someone who exploits the client's situation.

A face-to-face consultation was carried out when the client was in an emergency condition such as suicidal ideation, anxiety, and feeling very scared, selfinjury, and other emergency conditions. Preparation: (1) Make sure the room is sterilized. Spray the chairs, and the whole room; (2) Ensuring the completeness of health support devices (masks, hand sanitizers, plastics, and backup folders) and supporting work required (2 pens, ID card, assignment letter, or service form) available; (3) During the consultation explain the Covid-19 procedure, convey that this procedure must be followed for the safety and health of the client; (4) If the client requests pick up it will use the client pickup and delivery protocol.

The implementation of this protocol included: (1) Introduction by saying hello (salam), and then the consultation is focused on the legal information experienced by the client, legal efforts that can be made as an option and provide information related to the form 
of legal services that can be provided by the service institution; (2) Identifying client needs for other services not previously mentioned in the initial assessment; (3) Asking the client's need for further consultation and the schedule has been agreed between the client and TLH (legal service personnel); (4) Before the consultation closes, providing information if the client needs other services, the institution will call back from the same contact number to avoid the person acting on behalf of the institution and ask for the cost of the services provided are free; (5) The consultation concluded by conveying the conclusion of the conversation and saying thank you for your trust in the institution; (6) All results of the consultation will be recorded as well as reported in a worksheet; (7) All results of the consultation will be reported to the handling coordinator to be followed up for further assistance.

Protocol for Assisting in the Legal Process for Victims of Violence Against Women During the Covid-19 Pandemic

(1)Police Assistance Protocols for Scheduled Clients

Each institution should prepare the entire assistance process in the police a maximum of 1 day before the assistance schedule by paying attention to these protocols: (1) The officer confirms the accompaniment schedule to the investigator. This is to minimize the cancellation of the agenda or the victim waits too long in the police; (2) In addition to the schedule, officers also confirm the agenda of the process in the police. This can help officers to inform clients of the needs that must be prepared. Based on this agenda, officers can also estimate the support needs for the prevention of Covid-19;

Coordinate with investigators regarding efforts to minimize the spread of Covid19 in the inspection process (sterilization of examination rooms, the distance between seats within 2 meters, use of masks, wash hands or use hand sanitizers before and after the process). If the police cannot meet these standards, then the officer needs to prepare minimal requirements for the client, for example, masks, pens, and hand sanitizers; (4) Inform the client about the schedule and agenda in the police. Explain the Covid19 security procedure for the victim and convey that this procedure must be followed for the safety and health of the victim, including conveying the importance of being on time; (5) For the LP mentoring process, make sure an event is a criminal event (a brief analysis of the legal elements) and the client carries administrative requirements for 
the preparation of the report; (6) For the victim's counseling assistance agenda, ensure the certainty of the time of the examination; (7) The officer ensures that not many people accompany the victim, the priority is that those who have an interest in the legal process participate; (8) If the client requires to pick up, perform the client pick up procedure in Covid-19 emergency response situations.

On the day of assistance the things that must be concerned included: (1) Ensuring the completeness of health support devices (masks for clients, hand sanitizers, plastics, and backup folders) and supporting work required (2 pens, ID cards, assignment letters, or service forms) available; (2) If the client requires pick up, carry out the pickup process following the pickup protocol in the Covid-19 situation; (3) The officer uses a mask during the assistance process and explains the procedure during Covid-19; (4) The officer screens the potential risk of Covid-19 and the victim's health condition, if the victim's condition is not good it can be rescheduled (coordination with the police); (5) If the police process is finished, remind the client to return home immediately; (6) If the client needs to be delivered, carry out a client delivery protocol in the Covid-19 pandemic situation.
(2)Police Assistance Protocols for Unscheduled Clients

For unscheduled assistance, each institution continued to implement existing assistance protocols by paying attention to these protocols: (1) Ensuring the completeness of health support devices (masks for clients, hand sanitizers, plastics, and backup folders) and supporting work required (2 pens, ID cards, assignment letters, or service forms) available; (2) The officer uses a mask during the assistance process and explains the procedure during Covid-19; (3) The officer screened the potential risk of Covid-19 and the victim's health condition. If the victim's condition is not good, coordinate with the investigator for rescheduling; (4) If the police process is finished, remind the client to return home immediately. If it needs to be delivered, do the client delivery protocol according to the Covid-19 pandemic period.

\section{(3)Assistance Protocol in the Prosecutor's Office}

Each institution should prepare the entire process of assistance in the prosecutor's office a maximum of 1 day before the assistance schedule by paying attention to these protocols: (1) Ensure the schedule and agenda of assistance to the assigned prosecutor; (2) Coordinate regarding security procedures to prevent the spread of Covid-19 to the assigned prosecutors; (3) Inform the client about 
the schedule and agenda, as well as the completeness of required files; (4) The officer explains Covid-19 security procedures to the victim and conveys that this procedure must be followed for the safety and health of the victim, including the importance of being on time; (5) If the client needs to be delivered, do the client delivery protocol according to the Covid19 pandemic period.

On the day of assistance the things that must be concerned included: (1) Give a mask if the client is not wearing a mask; (2) Avoid shaking hands or other physical contacts even to show empathy; (3) If the victim needs to fill out and sign the document, make sure the victim uses a hand sanitizer first and afterward: (4) Remind if there is a violation of Covid-19 security procedures in the inspection process; (5) Ensuring the completeness of health support devices (masks, hand sanitizers, plastics, and backup folders) and supporting work required (2 pens, ID card, assignment letter, or service form) available; (6) The officer screens the potential risk of Covid-19 and the victim's health condition. If the victim's condition is not good, coordinate with the prosecutor regarding the possibility of rescheduling; (7) The officer ensures that not many people accompany the victim, the priority is that those who have an interest in the legal process participate.

\section{Protocol for Self-Rescue of Victims of Violence Against Women During the Covid-19 Pandemic}

The self-rescue plan was a step to reduce the risk of danger and violence in unsafe situations when the client must live with the perpetrators of violence or other family members. The rescue plan was submitted by the officer and discussed together with the client online when the client's safety criteria (online service guide) had been met and there was sufficient time to discuss it.

\section{CONCLUSION}

The implementations of large-scale social restrictions in Indonesia to prevent the wider spread of the Covid-19 pandemic, ultimately had socio-economic impacts, which then on a household also had the potential to cause domestic violence. In this situation, women were vulnerable to becoming victims of violence, especially during this pandemic. To overcome these socio-economic impacts, the government had taken efforts through social safety net programs, in the form of assistance/stimulus programs for those who are truly affected by this pandemic in their economy. Furthermore, to prevent the potential for violence against women during this pandemic, the government 
took the effort by implementing the Protocol on the Handling of Cases of Violence Against Women in the Covid-19 Pandemic Period. These efforts certainly required good synergy between the government and society. In addition, together in overseeing the implementation of the policy was also very important so that these efforts could run optimally, directly, and on target. So that, hopefully, the socio-economic impacts of the Covid-19 pandemic could be minimized and could be overcome immediately.

\section{REFERENCES}

Badan Nasional Penanggulangan Bencana (BNPB) Republik Indonesia. "Jaring Pengaman Sosial Kurangi Dampak Ekonomi Masyarakat di Tengah Pandemi Covid-19.” https://bnpb.go.id/berita/jaring -pengaman-sosial-kurangidampak-ekonomi-masyarakat-ditengah-pandemi-covid19, 16 April 2020, visited on 26 November 2020.

Burhanuddin, Chairul Ihsan, and Muhammad Nur Abdi. "Krisis Ekonomi Global dari Dampak Penyebaran Virus Corona (Covid-19)." AkMen 17, No. 1 (2020): 90-98. https://ejurnal.stienobelindonesia.ac.id/index.php/akme $\mathrm{n} /$ article/view/866.

Consuello, Yoshua. "Analisis Efektivitas Kartu Pra-Kerja di Tengah Pandemi Covid-19." 'Adalah 4, No. 1 (2020): 93-100. http://journal.uinjkt.ac.id/index. $\mathrm{php} /$ adalah/article/view/15479.

Dewanti, Asri Kusuma. "Darurat PHK di Tengah Corona." https://www.harianbhirawa.co.i d/darurat-phk-di-tengahcorona/, 07 April 2020, visited on 26 November 2020.

Engkus, and et. al. "Covid-19: Kebijakan Mitigasi Penyebaran dan Dampak Sosial Ekonomi di Indonesia."

http:/ / digilib.uinsgd.ac.id/30820 , 05 May 2020, visited on 26 November 2020.

Fakhruroji, Moch., and et. al. "Strategi Komunikasi Publik Penanganan Covid-19 di Indonesia: Perspektif Sosiologi, Komunikasi Massa, dan Agama." http:/ / digilib.uinsgd.ac.id/30753 /1/Strategi $\% 20$ Komunikasi $\% 20$ Publik\%20Penanganan \%20Covi d_KTI.pdf, visited on 26 November 2020.

Hadiwardoyo, Wibowo. "Kerugian Ekonomi Nasional Akibat Pandemi Covid-19." Baskara 2, No. 2 (2020): 83-91. https://jurnal.umj.ac.id/index.p hp/baskara/article/view/6207.

Hanoatubun, Silpa. "Dampak Covid-19 Terhadap Perekonomian Indonesia." EduPsyCouns: Journal of Education, Psychology and Counseling 2, No. 1 (2020): 146153. https://ummaspul.ejournal.id/Edupsycouns/article/ view/423.

Kementerian Kesehatan Republik Indonesia. "Peraturan Menteri Kesehatan No. 9 Tahun 2020." http://hukor.kemkes.go.id/uplo ads/produk_hukum/PMK_No_ 9_Th_2020_ttg_Pedoman_Pem 
batasan_Sosial_Berskala_Besar_ Dalam_Penanganan_COVID19.pdf, 03 April 2020, visited on 26 November 2020.

Kementerian Ketenagakerjaan Republik Indonesia. "Menaker: Badai Pasti Berlalu, Panggil Kembali Pekerja yang ter-PHK Nanti." https://www.kemnaker.go.id/ne ws/detail/menaker-badai-pastiberlalu-panggil-kembali-pekerjayang-ter-phk-nanti, 22 April 2020, visited on 26 November 2020.

Kementerian Permberdayaan Perempuan dan Perlindungan Anak Republik Indonesia. "SIMFONI PPA (Sistem Informasi Online Perlindungan Perempuan dan Anak)." https://kekerasan.kemenpppa.g o.id/ringkasan, 28 May 2020, visited on 28 May 2020

Kementerian Permberdayaan Perempuan dan Perlindungan Anak Republik Indonesia. "Protokol Penanganan Kasus Kekerasan Terhadap Perempuan di Masa Pandemi Covid-19." https:// covid19.go.id/storage/a $\mathrm{pp} / \mathrm{media} /$ Protokol $/ 2020 \% 20$ $\% 200205$

$\% 20$ PROTOKOL\%20LAYAN AN\%20PEREMPUAN\%20DI $\% 20$ PANDEMI $\% 20$ COVID $\% 2$ 0-\%208\%20PROTOKOL-1.pdf, 07 Mei 2020, visited on 26 November 2020.

Komisi Nasional Perempuan Republik Indonesia. "Angket Survey: Pemetaan Kondisi Layanan Pendampingan Perempuan Korban Kekerasan dan Kondisi Perempuan Pembela HAM di Masa Covid-19.” https://www.komnasperempuan .go.id/read-news-angket-surveypemetaan-kondisi-layanan- pendampingan-perempuankorban-kekerasan-dan-kondisiperempuan-pembela-ham-dimasa-covid-19, 08 May 2020, visited on 26 November 2020.

Kompas. "Fakta Lengkap Kasus Pertama Virus Corona di Indonesia." https:// nasional.kompas.com/re ad/2020/03/03/06314981/fakta -lengkap-kasus-pertama-viruscorona-di-indonesia, 03 March 2020, visited on 26 November 2020.

Maftuchan, Ah. "Program Tunai di Era Covid-19: Bantuan Tunai Korona atau Jaminan Penghasilan Semesta." https:// repository.theprakarsa.o $\mathrm{rg} /$ media/301094-policy-brief21-program-tunai-di-era-cov400baa3c.pdf, April 2020, visited on 26 November 2020.

Mardiyah, Rahmah Ainul, and R. Nunung Nurwati. "Dampak Pandemi Covid-19 Terhadap Peningkatan Angka Pengangguran di Indonesia." https://www.academia.edu/dow nload/63135109/Artikel_Studi_ Kependudukan_Rahma_Ainul_ Mardiyah_170310180076202004 29-102148-10xmp8n.pdf, visited on 26 November 2020.

Mufida, Anisa. "Polemik Pemberian Bantuan Sosial di Tengah Pandemic Covid-19." 'Adalab 4, No. 1 (2020): 159-166. http://journal.uinjkt.ac.id/index. $\mathrm{php} /$ adalah/article/view/15669.

Pakpahan, Aknolt Kristian. "Covid-19 dan Implikasi bagi Usaha Mikro, Kecil, dan Menengah." JIII: Jurnal Ilmiah Hubungan Internasional, Special Edition (2020): 59-64. http://journal.unpar.ac.id/index 
.php/JurnalIlmiahHubunganInte rnasiona/article/view/3870.

Rahmatullah, Indra. "Jaminan Hak Kesehatan Pekerja Work From Office Selama Masa PSBB Covid-19." 'Adalah 4, No. 1 (2020): 57-62. http://journal.uinjkt.ac.id/index. $\mathrm{php} /$ adalah/article/view/15425.

Rohmah, Siti Ngainnur. "Adakah Peluang Bisnis di Tengah Kelesuan Perekonomian Akibat Pandemi Corona?' 'Adalah 4, No. 1 (2020): 63-74. http://journal.uinjkt.ac.id/index. php/adalah/article/view/15448.

Satuan Tugas Penanganan Covid-19 Republik Indonesia. "Peta Sebaran." https://covid19.go.id/petasebaran, 26 November 2020, visited on 26 November 2020.

Satya, Putu Agung Nara Indra Prima. "Covid-19 dan Potensi Konflik Sosial." JIII: Jurnal Ilmiah Hubungan Internasional, Special Edition (2020): 39-45. http://journal.unpar.ac.id/index .php/JurnalIlmiahHubunganInte rnasiona/article/view/3867.

Sekretariat Kabinet Republik Indonesia. "Peraturan Pemerintah No. 21 Tahun 2020." https://jdih.setkab.go.id/PUUd oc/176085/PP_Nomor_21_Tah un_2020.pdf, 03 March 2020, visited on 26 November 2020.

Sekretariat Kabinet Republik Indonesia. "Program Jaring Pengaman Sosial."

https://setkab.go.id/gallery/pro gram-jaring-pengaman-sosial, 08 April 2020, visited on 26 November 2020.
Setiati, Siti, and Muhammad Khifzhon Azwar. "Covid-19 and Indonesia." Acta Medica Indonesiana 52, No. 1 (2020): 8489.

http://www.actamedindones.org /index.php/ijim/article/view/1 426.

Syafrida, and Ralang Hartati. "Bersama Melawan Virus Covid-19 di Indonesia." Salam 7, No. 6 (2020): $\quad$ 495-508. http://www.journal.uinjkt.ac.id/ index.php/salam/article/view/1 5325.

Wahyudi, M. S. "Opini Malang Post: Gerakan Sosial Atasi Dampak Ekonomi Covid-19." http://researchreport.umm.ac.id/index.php/AP I-

BAA/article/download/3558/3 478, 16 April 2020, visited on 26 November 2020.

World Health Organization (WHO). "Globally Confirmed Cases of Covid-19."

https:// covid19.who.int/?gclid= CjwKCAjw_LL2BRAkEiwAv2Y 3SbX6-

E_05NX0PIVKP26v7Y5kQLJ9 PSBZmSbcin880nW1zHcL6VW y7xoCz3MQAvD_BwE, 26 November 2020, visited on 26 November 2020.

World Health Organization (WHO). "Q\&A on Coronaviruses (Covid19): How does Covid-19 Spread?" https://www.who.int/emergenci es/diseases/novel-coronavirus2019/question-and-answershub/q-a-detail/q-acoronaviruses, 12 October 2020, visited on 26 November 2020. 
World Health Organization (WHO). "Q\&A on Coronaviruses (Covid19): What is a Covid-19?" https://www.who.int/emergenci es/diseases/novel-coronavirus2019/question-and-answershub/q-a-detail/q-acoronaviruses, 12 October 2020, visited on 26 November 2020.
Yusup, Deni Kamaludin, and et. al. "Pengaruh Bencana Covid-19, Pembatasan Sosial, dan Sistem Pemasaran Online Terhadap Perubahan Perilaku Konsumen dalam Membeli Produk Retail." http:/ / digilib.uinsgd.ac.id/30872 , 04 July 2020, visited on 26 November 2020. 